\title{
Release of Nitrogen and Phosphorus from Aquaculture Farms to Selangor River, Malaysia
}

\author{
Nobuyuki Kawasaki, M. R. M. Kushairi, Norio Nagao, Fatimah Yusoff, Akio Imai, and Ayato Kohzu
}

\begin{abstract}
The release of nitrogen and phosphorus from aquaculture ponds to Selangor River, Malaysia was estimated. The concentrations of nitrogen and phosphorus in aquaculture ponds were always higher than those in the river, their primary water source, indicating that the aquaculture ponds are sources of nitrogen and phosphorus in Selangor River. From the careful interview with aquaculture managers, the frequency of water exchange, the number of harvesting, and the amount of feeds added, the total volume of water released to the Selangor River was also obtained. The total amount of nitrogen and phosphorus added to each aquaculture pond was estimated to be about 700 $\mathrm{kg} \mathrm{N}$ and $60 \mathrm{~kg} P$ per year, respectively. About 100-200 $\mathrm{kg} \mathrm{N}$ and $10-15 \mathrm{~kg} P$ were estimated to be released with the waste water per pond per year, accounting for $20-30 \%$ of nitrogen and phosphorus in added feeds. It is important for us to precisely estimate the fates of nutrients for the better management and sustainable development of aquaculture industries. Our data may help to improve aquaculture management in future.
\end{abstract}

Index Terms-Rivers, aquaculture, nutrient release, eutrophication.

\section{INTRODUCTION}

The aquaculture has been one of the fastest growing agro-industries in the world including Malaysia. According to Food and Agriculture Organization (FAO) of the United Nations, the aquaculture production in Malaysia was about 150,000 tons in 2000 , but rapidly increased during the last decade. The production became 580,000 tons in 2010, about 3.5 times higher than that in 2000.

The environmental impacts of aquaculture industries on the surrounding environments include the release of the excess nutrients and antibiotics to the surrounding environments as well as the introduction of invading species. Since most of aquaculture practices except for most of shellfish aquacultures use feeds for optimal growth of aquaculture organisms, unused and dissolved feeds as well as feces can be released as the sources of excess nutrients during the water exchanges and discharges. These excess nutrients may cause the serious environmental impacts such as eutrophication [1],

Manuscript received March 5, 2015; revised May 12, 2015. This work was financially supported by the Malaysia Ministry of Higher Education under Fundamental Research Grant Scheme FRGS/1/2013/STWN01/UNISEL/02/1.

Nobuyuki Kawasaki and M. R. M. Kushairi are with Universiti Selangor, Malaysia (e-mail: kawasaki@unisel.edu.my, kushairi@gmail.com).

Fatimah Yusoff and Norio Nagao are with Universiti Putra Malaysia, Malaysia (e-mail: fatimahyus@gmail.com, monodonmonoceros@yahoo.co.jp).

Akio Imai and Ayato Kohzu are with National Institute for Environmental Studies, Japan (e-mail: aimai@nies.go.jp, kohzu@nies.go.jp). resulting in occurrence of the harmful algal blooms [2] and the depletion of oxygen due to the increase of microbial activities [3].

The occurrence of diseases is one of the most threatening events for aquaculture industries. The antibiotics have been used to cure the diseases caused by bacterial pathogens. However, the use of antibiotics would damage not only targeted bacterial pathogens, but also a number of non-pathogenic bacteria which may play significant roles in aquatic environments [4]. Since bacteria play a central role in microbial loop [5], the elemental and energy flow in aquatic ecosystems could be significantly altered by antibiotics, resulting in various negative impacts on natural ecosystems.

In addition, there are a number of non-native species which have been introduced as aquaculture organisms. Among them, tilapia species are considered to be the most common species. There have been a number of reports that tilapia which escaped from the aquaculture facilities are found in natural environments [6]. The significant ecological changes may have occurred in many aquatic environments. Despite these severe impacts caused by aquaculture practices, their impacts on the surrounding environments have not been well-studied in Malaysia yet.

Despite the importance of excess nutrient release from aquacultures, however, the accurate estimate of nutrient release from aquaculture ponds has not been well-studied. In this study, we estimated the amount of nitrogen and phosphorous released from aquaculture ponds along with Selangor River, Malaysia, and through the careful interviews with aquaculture managers, the estimation of fractions of the released nitrogen and phosphorus to the total nitrogen and phosphorous as the added feeds in a pond per year was calculated. The possible fates of the release and removal of nutrients added to aquaculture ponds as feeds were determined and discussed.

\section{MATERIALS AND METHODS}

\section{A. Sampling Sites and Procedures}

Three aquaculture farms were visited in this study, two brackish aquaculture farms, mainly producing black tiger shrimps and one freshwater aquaculture farm, mainly producing tilapia, catfish, and freshwater giant shrimp along Selangor River (Fig. 1). Each aquaculture farm used the water from Selangor River as the primary water source, and released the waste water to Selangor River during the water exchange and harvest basically without any treatments. The water samples were collected from the river next to each aquaculture farm, three shrimp aquaculture ponds with 
shrimps reared in 15 days, 90 days and 110 days, and three freshwater aquaculture ponds grown with tilapia, catfish, and freshwater giant prawn between November 2013 and February 2014.

Each water sample was collected using a bucket, pre-filtered by a $140-\mu \mathrm{m}$ mesh to remove large particles and rubbish before pouring it into a 2 - $\mathrm{L}$ polycarbonate bottle
(Nalgene). Then, it was stored in a cooler until brought back to Universiti Selangor (UNISEL). After coming back to UNISEL, the water samples were filtered by glass fiber filter (GF/F) filters (Whatman), and the filtered water was stored in 60-mL high-density-polyethylene (HDPE) bottles (Nalgene), 250-mL HDPE bottles (Nalgene) or both. All bottles were immediately frozen at $-30{ }^{\circ} \mathrm{C}$ and stored until sample analysis.

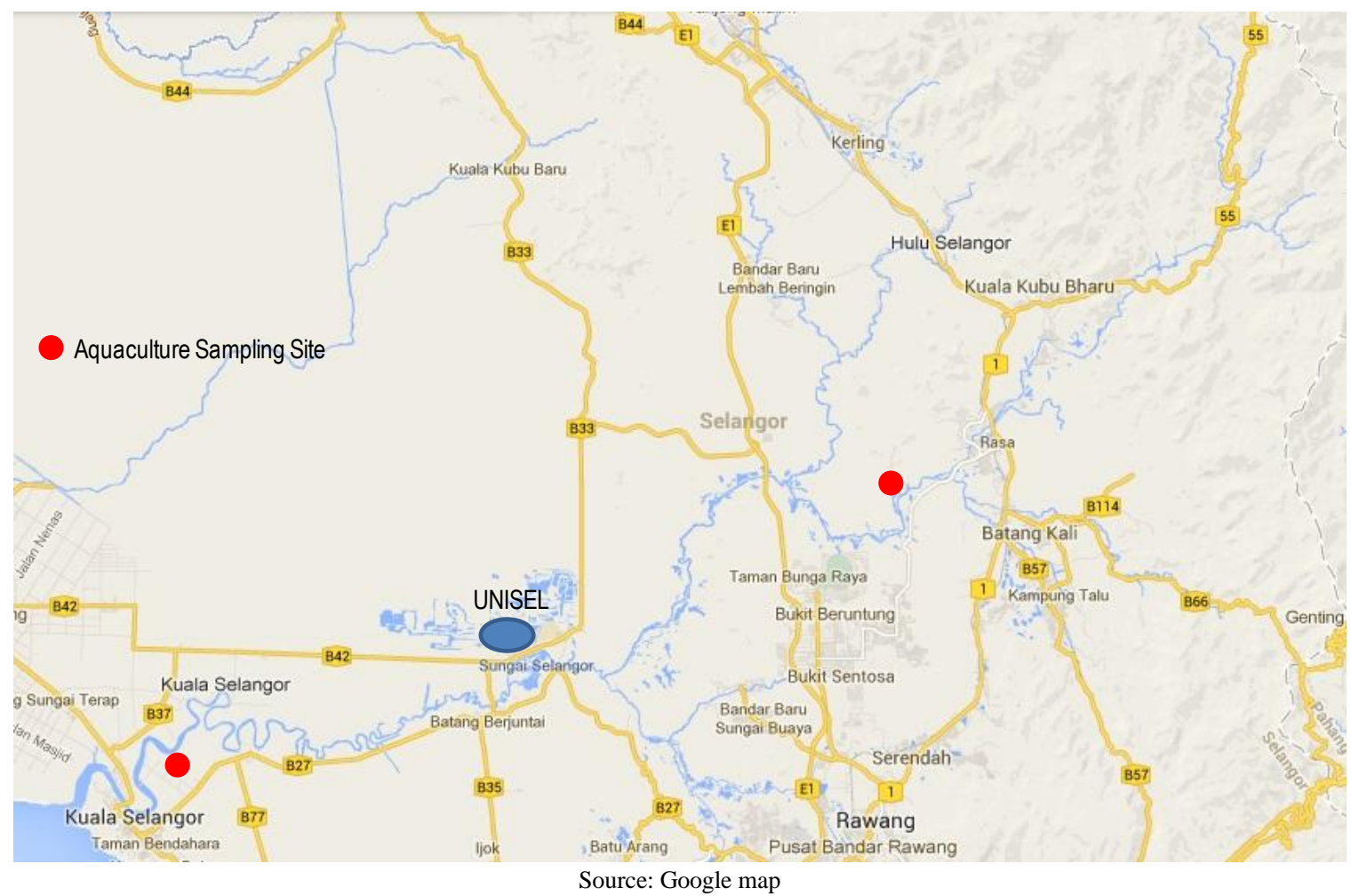

Fig. 1. Map of Selangor River and sampling sites in this study.

TABLE I: INFORMATION OF AQUACULTURE POND SIZE AND DEPTH AND VOLUME OF WATER DisCHARGED AND THE RELEASE OF TOTAL NiTROGEN (TN) AND PHOSPHORUS PER POND TO PER YEAR

\begin{tabular}{lccccc}
\hline \hline $\begin{array}{l}\text { Aquaculture } \\
\text { type }\end{array}$ & $\begin{array}{l}\text { Average size } \\
(\mathrm{ha})\end{array}$ & $\begin{array}{l}\text { Average depth } \\
(\mathrm{m})\end{array}$ & $\begin{array}{l}\text { Water discharged per pond per } \\
\text { year }\left(\mathrm{m}^{3} / \mathrm{y}\right)\end{array}$ & $\begin{array}{l}\text { TN released per pond per year } \\
(\mathrm{kg} \mathrm{N} / \mathrm{y})\end{array}$ & $\begin{array}{l}\text { TP released per pond per year } \\
(\mathrm{kg} \mathrm{N} / \mathrm{y})\end{array}$ \\
\hline Shrimp & 0.51 & 1.5 & 53.2 & 113.3 \\
Freshwater & 0.96 & 1.5 & 101.1 & 10.9 & 228.5 \\
& & & & & 14.6 \\
\end{tabular}

TABLE II: The Amount of FeEds, Nitrogen (N) AND Phosphorous (P) AdDED to Pond PER YeAR AND the Fraction of Nitrogen ANd PHOSPHOROus RELEASED TO THE SURROUNDING ENVIRONMENTS

\begin{tabular}{|c|c|c|c|c|c|}
\hline $\begin{array}{l}\text { Aquaculture } \\
\text { type }\end{array}$ & $\begin{array}{l}\text { Amount of feeds added to } \\
\text { pond per year }(\mathrm{kg} / \mathrm{y})\end{array}$ & $\begin{array}{l}\text { Amount of } \mathrm{N} \text { added to } \\
\text { pond per year }(\mathrm{kg} / \mathrm{y})\end{array}$ & $\begin{array}{l}\text { Amount of } \mathrm{P} \text { added to pond } \\
\text { per year }(\mathrm{kg} / \mathrm{y})\end{array}$ & $\begin{array}{l}\text { The fraction of } \mathrm{N} \\
\text { released }(\%)\end{array}$ & $\begin{array}{l}\text { The fraction of } \mathrm{P} \\
\text { released }(\%)\end{array}$ \\
\hline Shrimp & 11333 & 725 & 57 & 31.5 & 19.3 \\
\hline Freshwater & 10400 & 666 & 52 & 17.0 & 28.1 \\
\hline
\end{tabular}

\section{B. Sample Analyses}

Total dissolved nitrogen (TDN), total phosphorous (TDP), nitrate, ammonia and phosphate were measured for the nutrient analyses. TDN, nitrate, ammonia, TDP and phosphate were estimated using Lovibond MD-600 Photometer System (Tintometer GmbH, Germany). The method using MD-600 is a colorimetric assay and each nutrient is reacted with specific chemical reagents which produce the specific color. The nutrient concentrations are positively correlated with the strength of color. Each nutrient was measured in triplicate and the average was calculated.
The limit of detection of TDN, TDP, nitrate, ammonia and phosphate is $0.1 \mathrm{mg} / \mathrm{L} \mathrm{N}, 0.02 \mathrm{mg} / \mathrm{L} \mathrm{P}, 0.08 \mathrm{mg} / \mathrm{L} \mathrm{N}, 0.02$ $\mathrm{mg} / \mathrm{L} \mathrm{N}$, and $0.05 \mathrm{mg} / \mathrm{L} \mathrm{P}$, respectively. The coefficient variance $(\mathrm{CV})$ of each measurement was usually less than $2 \%$.

\section{Interviews with Aquaculture Managers}

The interviews with aquaculture managers were also conducted when the sampling sites were visited or the meeting appointment was made. The basic pond data, such as size and depth, the number of water exchanges, the number of harvesting, the annual amount of feeds used and other necessary information were obtained from the managers and 
their records. Based upon their data and the nutrient concentrations in ponds, the amount of nitrogen and phosphorus released from aquaculture ponds per year as well as the fraction of nitrogen and phosphorous from feeds which were released with the waste water were also estimated.

\section{RESULTS AND DISCUSSION}

The concentrations of total nitrogen (TN), total phosphorus (TP), nitrate, ammonia and phosphate from each aquaculture ponds are shown in Fig. 2 and Fig. 3. The average concentrations of TN TP, nitrate and ammonia were 1.0 and $5.3( \pm 1.3) \mathrm{mg} / \mathrm{L}, 0.007$ and $0.224( \pm 0.072) \mathrm{mg} / \mathrm{L}, 0.77$ and $1.70( \pm 0.44) \mathrm{mg} / \mathrm{L}$, and 0.11 and $0.78( \pm 0.18) \mathrm{mg} / \mathrm{L}$ in the river and shrimp aquaculture ponds, respectively (Fig. 2).

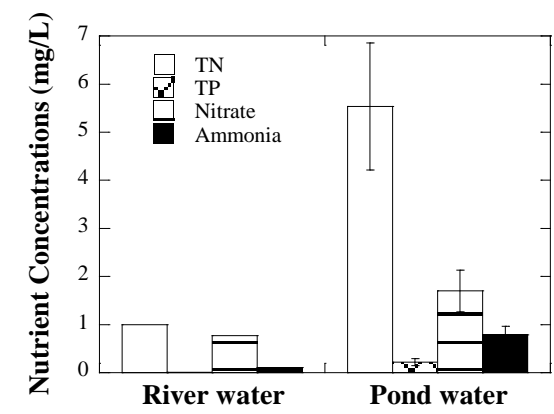

Fig. 2. Nutrient concentrations in river and shrimp aquaculture ponds.

The average concentrations of TN TP, nitrate and ammonia were 0.27 and $1.40( \pm 0.40) \mathrm{mg} / \mathrm{L}, 0.009$ and $0.153( \pm 0.031)$ $\mathrm{mg} / \mathrm{L}, 0.15$ and $0.43( \pm 0.09) \mathrm{mg} / \mathrm{L}$, and 0.048 and 0.021 $( \pm 0.013) \mathrm{mg} / \mathrm{L}$ in river and freshwater aquaculture ponds, respectively (Fig. 3).

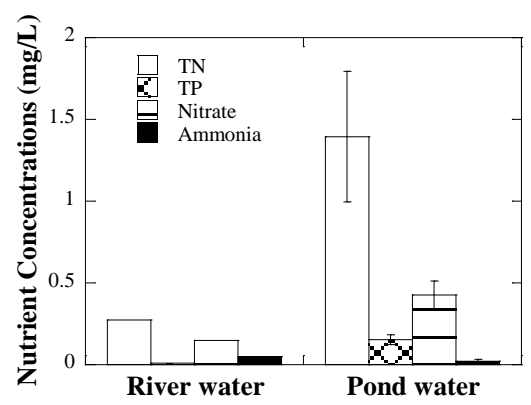

Fig. 3. Nutrient concentrations in river and freshwater aquaculture ponds.

These results indicate that nutrient concentrations in aquaculture ponds are usually much higher than those in the river ( $T$-test, $p<0.05)$. It is mainly due to the addition of feeds in aquaculture ponds. The ammonia concentration in freshwater aquaculture was lower than that in the river. During our visit, the significant number of phytoplankton was observed in freshwater aquaculture ponds in which the water color was dark green. Since some phytoplankton preferentially utilize ammonia [7], the ammonia concentration resulted in lower in the aquaculture ponds than in the river.

After the careful interviews with aquaculture managers, the average size and depth of aquaculture ponds, the volume of water discharged to the surrounding environment and the amount of feeds added to each aquaculture were calculated and shown in Table I. From the amount of water discharged and the differences of nitrogen and phosphorus between river and aquaculture ponds, total nitrogen (TN) and phosphorus (TP) released from each aquaculture ponds were calculated to be 228.5 and $10.9(\mathrm{~kg} / \mathrm{y})$ and 113.3 and $14.6(\mathrm{~kg} / \mathrm{y})$ in shrimp and freshwater aquaculture ponds, respectively.

Since there are about 12,000 brackish and 48,000 freshwater aquaculture ponds in Malaysia (Department of Environment, Malaysia: www.dof.gov.my/web/guest/aquaculture1), the significant amounts of nitrogen and phosphorous can be released to the surrounding environments, and contribute to eutrophication along the coastal areas, if all aquaculture practices were similar. In this study, the particulate fractions were not collected. If these fractions were included, the impacts of nitrogen and phosphorous released from aquaculture ponds on the surrounding environments should be even higher.

From the interview with aquaculture managers, the amount of feeds which were used per pond per year was provided. There were several different feeds used in aquaculture companies studied for this research, the accurate nutrient contents in each feed could not be obtained. However, since the fractions of proteins, a main nitrogen source, and of phosphorous were relatively constant [8], the protein contents in the feeds used in aquaculture ponds were assumed to be $40 \%$. Since $16 \%$ of proteins are nitrogen [9], it was estimated that $6.6 \%$ of feeds is nitrogen. The fraction of phosphorous in the feed was also assumed to $0.5 \%$.

Using these data and the amount of nitrogen and phosphorous released from the aquaculture ponds, the fraction of nitrogen and phosphorus from the added feeds released to the surrounding environments was also estimated (Table II).

Our calculation showed that $20-30 \%$ of both nitrogen and phosphorus added to feeds was released to the surrounding environments. The fates of nitrogen and phosphorus from feeds can include body mass of aquaculture organisms, dissolved and particulate forms in water column, sludge including unused feeds, fish feces and dead body, and for nitrogen, denitrification.

Feed conversion ratio (FCR) is usually used to estimate the efficiency of feed into body mass. According to the interview, FCR in their ponds was around 2. Since water usually accounts for about 80 per cent of the weight [10], about $10 \%$ of feeds could be incorporated into body mass. Nitrogen and phosphorus in particulate forms can include biological components such as phytoplankton, abiological components such as feed remnant. This fraction could be as high as that in the dissolved fraction. The sludge may be another important source of nitrogen and phosphorus to the surrounding environments. The removal of sludge was used to be operated using a high pressure water to the surrounding environment. However, the recent practice including one aquaculture company we sampled uses the drying procedure in which the sludge is completely dried for a period of one month before starting a new batch. The removal of nitrogen is expected due to denitrification in this practice.

The further study is needed to more precisely estimate the fates of nitrogen and phosphorus from the feeds. It is also important to estimate how the released nitrogen and phosphorus from aquaculture ponds are incorporated in 
natural ecosystems. It may be possible to use isotopic compositions of carbon and nitrogen to distinguish them between aquaculture and natural origins because the isotopic compositions of carbon and nitrogen in aquaculture ponds are completely dependent upon those of feeds, which may have different isotopic composition from the natural one. Our preliminary data has shown some differences.

Aquaculture has been regarded as important food sources to support ever-growing population in the $21^{\text {st }}$ century, and must continue to grow to meet the demand. For the sustainable development of aquaculture industries, it is important to precisely understand the fates of nitrogen and phosphorus from aquaculture practices, and it will lead to the better management as well as conservation of our precious environments.

\section{ACKNOWLEDGMENT}

Sampling was supported by numerous undergraduate students including Yuvalin Krishn A/P Krishnan, Nor Farihah Bt Muda, Muhammad Balqis Bin Azizul Rahim, Tulip Adzarlia Mohamad Adzali, Yaswini A/P Subramaniam, Vickneswary A/P Vadivelu and Fadzrina Dolhan, and a master student, Daniel Ramachandran. We also thank Yuki Imaizumi at Universiti Putra Malaysia for the support of nutrient analyses, aquaculture managers to provide us various useful information about the aquaculture practices, and officers in local fishery districts to provide us information of aquaculture companies.

\section{REFERENCES}

[1] F. U. P. González, J. A. Herrera-Silveira, and M. L. Aguirre-Macedo, "Water quality variability and eutrophic trends in karstic tropical coastal lagoons of the Yucatán Peninsula," Estuarine, Coastal and Shelf Science, vol. 76, pp. 418-430, 2008.

[2] H. W. Paerl, "Coastal eutrophication and harmful algal blooms: Importance of atmospheric deposition and groundwater as 'new' nitrogen and other nutrient sources," Limnology and Oceanography, vol. 42, pp. 1154-1165, 1997.

[3] R. J. Diaz and R. Rosenberg, "Spreading dead zones and consequences for marine ecosystems," Science, vol. 321, pp. 926-929, 2008.

[4] F. C. Cabello, "Heavy use of prophylactic antibiotics in aquaculture: a growing problem for human and animal health and for the environment," Environmental Microbiology, vol. 8, pp. 1137-1144, 2006.

[5] F. Azam, T. Fenchel, J. G. Field, J. S. Gray, L. A. Meyer-Reil, and F. Thingstad, "The ecological role of water-column microbes in the sea," Marine Ecology Progress Series, vol. 10, pp. 257-263, 1983.

[6] S. S. D. Silva, R. P. Subasinghe, D. M. Bartley, and A. Lowther "Tilapias as alien aquatics in Asia and the Pacific: A review," FAO Fisheries Technical Paper, vol. 453, p. 65, 2004.

[7] Q. Dortch, "The interaction between ammonium and nitrateuptake in phytoplankton," Marine Ecology Progress Series, vol. 61, pp. 183-201, 1990.

[8] A. G. J. Tacon, "Standard methods for the nutrition and feeding of farmed fish and shrimp," Washington DC: Argent Laboratories Press, 1990, p. 454.

[9] S. Craig and L. A. Helfrich, "Understanding fish nutrition, feeds, and feeding," Virginia Cooperative Extension, 2009.

[10] M. I. Yeannes and M. E. Almandos, "Estimation of fish proximate composition starting from water content," Journal of Food Composition and Analysis, vol. 16, pp. 81-92, 2003.

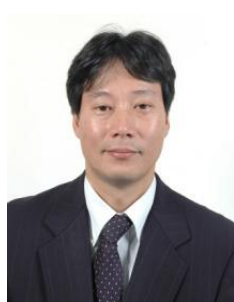

Nobuyuki Kawasaki was born in Osaka, Japan on May 5, 1972. He has had a B.S. in bioengineering in Faculty of Engineering, the Department of Bioengineering, Soka University, Japan in 1995. He has had his M.S. degree majoring in biological oceanography at College of Oceanic and Atmospheric Sciences, Oregon State University, USA in 1999. He has had his PhD degree majoring in marine science at Marine Science Program, University of South Carolina, USA in 2006.

He has worked at National Institute for Environmental Studies in Tsukuba, Japan as post-doc fellow between 2006 and 2011. Since 2011, he has been working at Faculty of Science and Biotechnology, Universiti Selangor, in Malaysia as a senior lecturer. He recent published some papers. His current research interests include the water quality, microbiology, aquatic organic matter, aquatic elemental cycles, and size exclusion chromatography.

Dr. Kawasaki is currently a member of American Society of Microbiology, Association for the Sciences of Limnology and Oceanography, Japan Society on Water Environment and Asia-Pacific Chemical, Biological\& Environmental Engineering Society. 